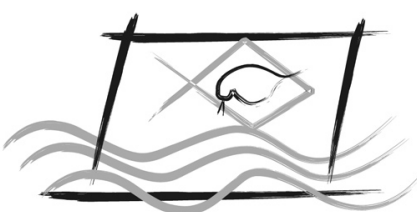

ECOTOX - BRASIL

\title{
Acute sensitivity to Nitokra sp benthic copepod to potassium dichromate and ammonia chloride
}

\author{
E.C.P.M. de Sousa ${ }^{1 *}$, L.P. Zaroni ${ }^{1}$, T.U. Bergmann Filho ${ }^{1}$, L.A. Marconato ${ }^{2}$, \\ A.A. Kirschbaum ${ }^{1} \&$ M.R. GaSPARro ${ }^{1}$ \\ ${ }^{1}$ Instituto Oceanográfico, IOUSP, Cidade Universitária, CEP 05508-900, São Paulo/SP, Brazil. \\ phone: 055.11.3091.6572,edvinett@usp.br \\ ${ }^{2}$ FUNDESPA - Fundação de Pesquisas e Estudos Aquáticos, São Paulo/SP, Brazil.
}

(Received December 05, 2010; Accept August 24, 2011)

\begin{abstract}
The present study assesses acute toxicity of non-ionized ammonia and potassium dichromate using the estuarine benthic copepod Nitokra sp from laboratory cultures. Bioassays with non-ionized ammonia sensitivity were carried out, and the mean. Bioassays with non-ionized ammonia sensitivity were carried out, and the mean of LC(I $)_{50-96 \mathrm{~h}}$ was $1.7 \mathrm{mg} . \mathrm{L}^{-1}$. $-\mathrm{LC}(\mathrm{I})_{50-96 \mathrm{~h}}$ was $1.7 \mathrm{mg} . \mathrm{L}^{-1}$. Potassium dichromate was used as reference substance in two distinct periods of exposure and the mean LC(I $)_{50-48 \mathrm{~h}}$ and $\mathrm{LC}(\mathrm{I})_{50-96 \mathrm{~h}}$ values were $55.61 \mathrm{mg} \cdot \mathrm{L}^{-1}$ and $21.70 \mathrm{mg} . \mathrm{L}^{-1}$, respectively. The organism showed sensitivity to the toxic agents used and good reproducibility of results, indispensable factors for use in ecotoxicological assays.
\end{abstract}

Keywords: bioassay, acute sensitivity test, potassium dichromate, ammonium chlorinate, estuarine copepod

\section{Resumo}

\section{Sensibilidade aguda do copépodo bentônico Nitokra sp ao dicromato de potássio e cloreto de amônia}

O presente estudo avalia a toxicidade aguda da amônia não ionizada e do dicromato de potássio ao copépodo bentônico estuarino Nitokra sp cultivado em laboratório. O valor médio da CL(I) ${ }_{50-96 \mathrm{~h}}$ foi $1,7 \mathrm{mg} . \mathrm{L}^{-1}$ de amônia não ionizada, e para a substância de referência os valores médios foram $\mathrm{CL}(\mathrm{I})_{50-48 \mathrm{~h}}=55,61 \mathrm{mg} \cdot \mathrm{L}^{-1} \mathrm{e} \mathrm{CL}(\mathrm{I})_{50-96 \mathrm{~h}}=21,70 \mathrm{mg} \cdot \mathrm{L}^{-1}$ de dicromato de potássio. O organismo apresentou sensibilidade aos agentes tóxicos utilizados e boa reprodutibilidade de resultados, fatores esses indispensáveis para uso em ensaios ecotoxicológicos.

Palavras-chave: bioensaio, testes de sensibilidade, dicromato de potássio, cloreto de amônia, copépodo estuarino

*Corresponding author: e-mail: edvinett@usp.br 


\section{INTRODUCTION}

An important step for advancing the field of marine ecotoxicology is finding appropriate organisms for the development of toxicity tests (Kwok et al., 2008). Some benthic harparcticoid copepods have many characteristics that make them suitable for organism-tests in evaluating toxicity in sediment and water samples.

Benthic copepods are broadly applied in chronic and acute toxicity evaluation of environmental samples and specific contaminants. As examples of the use of benthic copepods in toxicity testing, Nitocra lacustris and Schizopera knabeni were used in analyses of sublethal toxicity with phenanthrene (Lotufo \& Fleeger, 1997); Amphiascus tenuiremis species are used in tests with sediment spiked with metals; organophosphorous pesticides azimphosmethyl and a crude oil soluble fraction (Hagopian-Schlekat et al., 2001; Klosterhaus et al., 2003; Bejarano et al., 2004); Nitocra spinipes was used in the evaluation of mixtures with organic polymers (Breitholtz et al., 2008); Tisbe battagliai, Tigriopus fulvus and Robertsonia propinqua were used in estuarine sediment toxicity assays (Hack et al., 2008; Pane et al., 2008; Araújo et al., 2010).

The availability of organisms in sufficient number from laboratory cultures, ease of culture maintenance, tolerance to a broad range of abiotic factors such as granulometry, salinity and temperature, and their permanence during the entire life cycle in sediment and reduced size, are desirable test species characteristics (Lamberson et al., 1992; Rand et al., 2000; Domingues \& Bertoletti, 2006). The harpacticoid copepod species listed above possess these characteristics.

Coull (1990), states that harparcticoids are the second most abundant meiofauna taxon and are an important link in the trophic chain, serving as food for a variety of fish and invertebrates in the juvenile phase.

Ecological studies in the structure of this community consider these organisms as sensible indicators of pollution in the benthic environment. Chemical-effect study of contaminants in benthic organisms indicate that copepods are frequently more vulnerable to the effect of some classes of contaminants than other benthic invertebrates (Coull \& Chandler, 1992).

The benthic harparcticoid copepod Nitokra sp was isolated from several species collected in the sediment of Cananéia (SP) estuarine region and fully adapted to culture conditions in the Laboratory of Marine Ecotoxicology and Microphytobenthic (LEcotox) of the Oceanographic Institute of the University of São Paulo in Brazil.

In marine and estuarine environments, ammonia is a natural element, discharged as a product of excretion by invertebrates and other animals from these environments (Mackin \& Aller, 1984). In this form, its toxic effect is practically insignificant compared with the amount released from industrial effluent and sewage.

Even occurring naturally as excretion product or nutrient, ammonia can interfere with the survival and reproduction of marine organisms, some of which are sensitive planktonic species and others, are less sensitive benthic invertebrates, favorable to higher levels of this nutrient (Lapota et al., 2000). Knowledge of sensitivity of marine species to ammonia used in toxicity tests is very important because this nutrient can be present in higher concentrations in environmental samples.

In all aquatic environments, ammonia can occur in two modes; the ionized $\left(\mathrm{NH}_{4}^{+}\right)$mode, which is assimilated as nutrient by primary producers and has low permeability across the cellular membrane, and the non-ionized mode $\left(\mathrm{NH}_{3}\right)$, which is usually toxic because of high lipid solubility, favoring diffusion across cell membranes (Bower \& Bidwell, 1978; Thurston et al., 1979; Rebelo, 1996; Frias-Espericueta et al., 2000; Boardman et al., 2004).

Toxicity tests with reference substances are frequently used to evaluate the sensitivity and physiological state of a test-organism lot. Moreover, they serve to verify the reproducibility, and are employed in interlaboratory analyses (Rand et al., 2000).

Potassium dichromate is frequently used as a reference substance. Therefore, according to Rand, et al. (2000), the contaminant must be stable and cause, in low concentrations, a fast lethal effect.

The aim of this work is to present results about the acute sensitivity of Nitokra sp to ammonia chloride and potassium dichromate, providing valuable information in widening the use of this species in ecotoxicological studies.

\section{MATERIAL AND METHODS}

\section{Test-organism}

Nitokra sp is typically benthic and estuarine in areas with salinity varying between 5 and 30 (Lotufo \& Abessa, 2002). It feeds on microorganisms, organic matter associated with the sand grains and seaweed and grazing on single food particles (Ruppert et al., 1996). According to Giere (2009), harpacticoids have often been considered mainly "detritus feeders", ingesting primarily bacteria, protozoires and diatom cells.

The culture of Nitokra sp is monospecific and was established in 1998 from organisms collected from the sediment surface from the intertidal zone of Spartina sp banks in the Cananéia Estuary in the southern coast of the state of São Paulo (Lotufo \& Abessa, 2002).

The organisms were maintained in a $1 \mathrm{~L}$ glass with 750 $\mathrm{mL}$ of reconstituted seawater and salinity of $23 \pm 3$. The temperature varied between $20^{\circ}$ and $25^{\circ} \mathrm{C}$. The cultures were fed three times a week with a microalgae mixture containing Chaetoceros, Chlorophucea, Dunaniela, Hillea, Isochrysis, Nannochloropsis, Odontela, Pavlova, Pyrocystis, Thalassiosira, Prorocentrum, Synecococcus and supplemental food made of $0.5 \mathrm{mg}$ fish ration diluted in $100 \mathrm{~mL}$ of reconstituted seawater prepared at salinity $22 \pm 2$. 


\section{Acute toxicity test}

Adult males and non-ovigerous females were used as testorganisms. Organisms were selected under stereomicroscope (25x) using Petri plates with reconstituted seawater, after sieving part of the culture content using a $125 \mu \mathrm{m}$ mesh.

The culture water was reconstituted seawater, prepared by adding artificial sea salts (RED SEA Fish farm) to de-ionized water, aged for at least 1 day and maintained under constant aeration until the moment of its use.

Five tests of acute effect with ammonia chloride reagent $\left(\mathrm{MERCK}^{\circledR}\right)$, in salt form, were performed. The stock solution was prepared by adding $500 \mathrm{mg}$ of ammonium chloride per $1 \mathrm{~L}$ of reconstituted seawater. Test solutions were prepared by adding appropriate amounts of stock solution in concentrations $5.0 ; 10.0 ; 50.0 ; 100.0$ and $500.0 \mathrm{mg} . \mathrm{L}^{-1}$ of ammonium chloride. The tests were conducted during a 96-hour exposure period with 5 replicates per concentration, in Petri plates with $20 \mathrm{~mL}$ capacity. Ten adult males and non-ovigerous were exposed in each replicate. The entire test system was kept at $25^{\circ} \mathrm{C}$ in a acclimatized room with a natural photoperiod.

After the exposure period, live and dead organisms were observed and counted under a stereomicroscope. Physicalchemical parameters, i.e., salinity, $\mathrm{pH}$ and temperature, were measured at the beginning and at the end of each test. These parameters and total ammonia (nominal concentration) were used to determine non-ionized ammonia concentration according to Whitfield (1978). The Trimmed Spearman-Karber program was used to calculate the $\mathrm{LC}_{50}$ values (Hamilton et al., 1977).

The tests of acute effect with potassium dichromate were carried out similarly to the tests with ammonia chloride. Five tests were performed during a period of 48 hours of exposure with 5 replicates per concentration between April and May of 2004. From 2004 to 2009, twelve more tests were performed, for a period of 96 hours/test, with 4 replicates per concentration. The nominal concentration was $6.25 ; 12.5 ; 25.0 ; 50.0$ and $100.0 \mathrm{mg} . \mathrm{L}^{-1}$ of potassium dichromate $\left(\mathrm{K}_{2} \mathrm{Cr}_{2} \mathrm{O}_{7}\right)$, for both periods of exposure.

After each test, the live and dead organisms were observed and counted under stereomicroscope. The Trimmed Spearman-Karber program was used to calculate the $\mathrm{LC}_{50-48 \mathrm{~h}}$ and LC(I) $)_{50-96 \mathrm{~h}}$ values (Hamilton et al., 1977). The sensitivity limits for both periods of exposure were calculated (average $\pm 2 \mathrm{DP}$ ), according to Zagatto \& Bertoletti (2006). Subsequently, a sensitivity control chart was developed for Nitokra sp to $\mathrm{K}_{2} \mathrm{Cr}_{2} \mathrm{O}_{7}$, for the exposure period of 96 hours.

\section{RESULTS AND DISCUSSION}

Evaluation of acute toxic effects must be carried out using accurate and reproducible methods. Mortality during laboratory exposure is a widely used endpoint for comparing the effects of organisms exposed to an environmental sample or specific chemicals with exposure to control or reference material.

The $\mathrm{LC}_{50}$ - lethal concentration that causes $50 \%$ organism mortality during a determined period of time - is frequently used to express the concentration effect of a chemical agent to test-organisms and also to compare toxicity between testspecies and toxic agents.

According to Buratini \& Bertoletti (2006), the $\mathrm{LC}_{50}$ percentage calculation of effect are based on transformed data and assume a normal distribution, making it possible to trace a straight line through the points, allowing the attainment of a median concentration, which corresponds to the concentration that causes $50 \%$ mortality of the exposed organism. In the event that similar curves were established, the optimum level of correlation would be presented in the $50 \%$ level of effect. Therefore, the choice of this percentage is related to accuracy and reproducibility results.

According to Whitfield (1974), Frias-Espericueta et al. (2000) and Boardman et al. (2004), the concentration of ionized ammonia in the marine environment is highly influenced by $\mathrm{pH}$ and also varies according to temperature, salinity and pressure. The rise of temperature, $\mathrm{pH}$ and salinity cause the dissociation of $\mathrm{NH}_{4}{ }^{+}$ionized to $\mathrm{NH}_{3}$ non-ionized.

In regard to Nitokra sp sensitivity to non-ionized ammonia, the $\mathrm{LC}(\mathrm{I})_{50-96 \mathrm{~h}}$ rate varied between 0.56 and $2.89 \mathrm{mg} . \mathrm{L}^{-1}$ of $\mathrm{NH}_{3}$, and the average value was $1.7 \mathrm{mg} \cdot \mathrm{L}^{-1}$ of $\mathrm{NH}_{3}$.

The analyzed environmental parameters such as salinity, $\mathrm{pH}$ and temperature at the beginning and at the end of the tests influenced the equilibrium between $\mathrm{NH}_{4}^{+}$and $\mathrm{NH}_{3}$ levels and in $\mathrm{LC}_{50-96 \mathrm{~h}}$ results. The higher the salinity, the lower the rates of $\mathrm{LC}_{50}$ (Table 1), and, therefore, the ammonia chloride was more toxic. The rise in temperature corresponded to higher $\mathrm{LC}_{50}$, and consequently, to lower toxicity.

The average $\mathrm{NH}_{3} \mathrm{LC}_{50-96 \mathrm{~h}}$ values for Nitokra sp derived in this study, $1.7 \mathrm{mg} . \mathrm{L}^{-1}$, was similar to $\mathrm{LC}_{50-72 \mathrm{~h}}$ values of 1.83 mg. $L^{-1}$ reported by Abessa (2002) for the dweller amphipod Tiburonella viscana, and similar to the $\mathrm{LC}_{50-48 \mathrm{~h}}$ value of 1.03 mg. $\mathrm{L}^{-1}$ reported by Boardman et al. (2004) for mysid shrimp (Mysidopsis bahia) and a $\mathrm{LC}_{50-96 \mathrm{~h}}$ value of $1.66 \mathrm{mg} . \mathrm{L}^{-1}$ for ghost shrimp (Palaemonetes pugio). Both Nitokra sp and Tiburonella viscana are benthic invertebrates which are relatively more tolerant to ammonia and non-ionized ammonia (Lapota et al., 2000).

For Leptocheirus plumulosus, a benthic amphipod frequently used as a test-organism in sediment exposures, levels above $60.0 \mathrm{mg} . \mathrm{L}^{-1}$ of $\mathrm{NH}_{4}^{+}$and $0.8 \mathrm{mg} . \mathrm{L}^{-1}$ of $\mathrm{NH}_{3}$ with $\mathrm{pH} 7.7$ lead to effects in survival and reproduction USEPA (2001). Kalliapseudes schubartii, a presented higher tolerance to nonionized ammonia, as evidenced by the reported $\mathrm{LC}_{50-7 \text { days }}$ value for $\mathrm{NH}_{3}$ of $3.16 \mathrm{mg} . \mathrm{L}^{-1}$ (Maraschin et al., 2008).

Ammonia is typically naturally present in environmental samples, especially sediments. Therefore, knowledge of sensitivity of test-organisms is desirable and valuable. Evaluation of species sensitivity to chemicals used as reference substance, such as potassium dichromate, is likewise desirable and warranted. Despite this, it is necessary to have a parallel, in this case. The mean LC(I $)_{50-48 \mathrm{~h}}$ value for Nitokra sp was $55.61 \mathrm{mg} \cdot \mathrm{L}^{-1}$ for $\mathrm{K}_{2} \mathrm{Cr}_{2} \mathrm{O}_{7}$ and the sensitivity limits were 10.19 and $101.03 \mathrm{mg} \cdot \mathrm{L}^{-1}$. The $\mathrm{LC}(\mathrm{I})_{50-48 \mathrm{~h}}$ rates obtained in the 5 replicate tests are presented in Table 2. 
Table 1 - Physical chemical parameters, ammonium chloride $\mathrm{LC}(\mathrm{I})_{50-96 \mathrm{~h}}$ and non ionized ammonia $\mathrm{LC}_{50-96 \mathrm{~h}}$.

\begin{tabular}{|c|c|c|c|c|c|c|c|c|c|c|c|c|}
\hline \multirow{2}{*}{$\begin{array}{l}\text { Number } \\
\text { of } \\
\text { Test }\end{array}$} & \multicolumn{2}{|c|}{ Salinity } & \multicolumn{2}{|c|}{ pH } & \multicolumn{2}{|c|}{$\begin{array}{c}\text { Temperature } \\
\left({ }^{\circ} \mathrm{C}\right) \\
\end{array}$} & \multirow{2}{*}{\multicolumn{2}{|c|}{$\begin{array}{c}\mathbf{L C}(\mathbf{I})_{50-96 \mathrm{~h}} \\
\mathbf{N H}_{4}^{+} \\
\left(\mathrm{mg} \cdot \mathrm{L}^{-1}\right)\end{array}$}} & & & \multirow{2}{*}{$\begin{array}{c}\mathbf{L C}_{50-96 \mathbf{h}} \\
\mathbf{N H}_{3} \\
\left(\mathrm{mg} \cdot \mathrm{L}^{-1}\right)\end{array}$} & \\
\hline & Initiate & End & Initiate & End & Initiate & End & & & & & & \\
\hline 1 & 25.00 & 27.00 & 8.71 & 7.51 & 23.00 & 17.00 & & $>100$ & & & $>0.836$ & \\
\hline 2 & 27.00 & 26.00 & 8.54 & 7.46 & 23.00 & 17.00 & 2 & $\begin{array}{ccc}1 & 7 & 6 \\
(191.05-247.87)\end{array}$ & & 1 & $\begin{array}{c}. \\
(1.32-1.64)\end{array}$ & 7 \\
\hline 3 & 23.17 & 23.83 & 8.54 & 7.79 & 29.00 & 28.00 & 9 & $\begin{array}{cc}3 & 4 \\
(69.00-126.55)\end{array}$ & 5 & 2 & $\begin{array}{c}8 \\
(2.27-3.66)\end{array}$ & 9 \\
\hline 4 & 26.50 & 27.50 & 8.54 & 7.61 & 22.00 & 21.00 & 3 & $\begin{array}{cr}8 & 3 \\
(21.96-67.04)\end{array}$ & 7 & 0 & $\begin{array}{c}5 \\
(0.35-0.88)\end{array}$ & 6 \\
\hline 5 & 23.17 & 24.17 & 8.30 & 7.86 & 23.00 & 23.00 & 6 & $\begin{array}{cc}0 & 2 \\
(39.18-92.70)\end{array}$ & 7 & 1 & $\begin{array}{c}8 \\
(1.29-2.71)\end{array}$ & 7 \\
\hline
\end{tabular}

Table 2 - Potassium dichromate LC(I $)_{50-48 \mathrm{~h}}$ and its respective confidence limits, mean value, standard deviation and variation coefficients of each test.

\begin{tabular}{lccc}
\hline \multirow{2}{*}{$\begin{array}{l}\text { Number of } \\
\text { Test }\end{array}$} & $\begin{array}{c}\text { LC(I) } \\
\text { 50-48h } \\
\left(\mathrm{mg.L} \mathrm{L}_{\mathbf{2}} \mathbf{C r}_{2} \mathbf{O}_{7}\right.\end{array}$ & \multicolumn{2}{c}{ Confidence Limits } \\
\cline { 3 - 4 } & 46.29 & Lower & Higher \\
\hline 1 & 20.69 & 16.00 & 71.54 \\
2 & 62.09 & 46.95 & 82.12 \\
3 & 75.15 & 69.48 & 81.33 \\
4 & 73.84 & 67.81 & 80.41 \\
5 & 55.61 & 46.04 & 68.43 \\
Mean Value & 22.71 & 23.37 & 23.69 \\
Standard Deviation & 40.83 & 50.76 & 34.61 \\
Coefficient of Variation & & &
\end{tabular}

For the 96-hour exposure period, the average $\mathrm{LC}(\mathrm{I})_{50}$ was $21.70 \mathrm{mg} . \mathrm{L}^{-1}$ of $\mathrm{K}_{2} \mathrm{Cr}_{2} \mathrm{O}_{7}$ and the sensitivity limits were 10.26 and $33.13 \mathrm{mg} \cdot \mathrm{L}^{-1}$ of $\mathrm{K}_{2} \mathrm{Cr}_{2} \mathrm{O}_{7}$. These results have been used to assemble a control chart for the sensitivity of this test organism to $\mathrm{K}_{2} \mathrm{Cr}_{2} \mathrm{O}_{7}$ (Table 3 and Figure 1).

The $\mathrm{LC}(\mathrm{I})_{50}$ mean value and the higher and lower limits of sensitivity were lower for 96-h exposures than for 48-h exposures. Moreover, the standard deviation and coefficient of variation (standard deviation expressed as a percentage of the mean) values were also lower for $96-\mathrm{h}$ exposures, likely because of the higher number of tests performed to comprise the mean value.

In addition, according to USEPA (1992) many factors such as culture and physiological conditions could contribute to the variability of these toxicity results from short-term exposures when using different pools of organisms.

According to Environment Canada (1990), results are considered adequate when the coefficient of variation is between $20 \%$ and $30 \%$. The experiment with Nitokra sp and potassium dichromate presented a coefficient of variation value of $23.56 \%$, which indicates success in reproducibility.

Nitokra sp showed more sensitivity to potassium dichromate compared to freshwater fish such as Piracactus mesopotamicus (pacu); Hyphessobrycon eques (weed-thick) and Phalloceros. caudimaculttus (guarú) (Cruz et al., 2008), and less sensitivity than embryos of echinoids such as Mellita quinquesperforata, Arbacia lixula and Lytechinus variegatus, frequently used in aquatic tests in studies developed by Resgalla \& Laitano (2002); Laitano et al. (2008) and Maximo et al. (2008), respectively (Table 4).

In regard to other crustaceans, Nitokra sp showed more tolerance to potassium dichromate than Tiburonella viscana (Abessa \& Sousa, 2003) and the harpacticoid copepod Tisbe biminiensis (Araújo-Castro et al., 2009). The measure of sensitivity between each species to potassium dichromate through the $\mathrm{LC}_{50}$ rates is expressed in Table 4 .

Although Nitokra sp showed less sensitivity to potassium dichromate, in regard to other species of crustaceans used in toxicity tests, the use of this benthic copepod in ecotoxicological assays is very promising due to its versatility. According to Lotufo \& Abessa (2002), this organism survives and reproduces in a wide range of salinities, enabling it to be applied in evaluations of the toxicity of isolated substances,

Table 3 - Potassium dichromate LC(I) ${ }_{50-96 \mathrm{~h}}$ and its respective confidence limits, mean value, standard deviation and variation coefficients.

\begin{tabular}{|c|c|c|c|}
\hline \multirow{2}{*}{ Tests } & \multirow{2}{*}{$\begin{array}{c}\mathbf{L C}(\mathbf{I})_{50-96 \mathrm{~h}} \mathbf{K}_{2} \mathbf{C r}_{2} \mathbf{O}_{7} \\
\left(\mathrm{mg} \cdot \mathrm{L}^{-1}\right)\end{array}$} & \multicolumn{2}{|c|}{ Confidence Limits } \\
\hline & & Lower & Higher \\
\hline may/04 & 23.21 & 18.65 & 28.89 \\
\hline jun/04 & 29.88 & 23.14 & 38.59 \\
\hline aug/04 & 16.08 & 12.94 & 19.99 \\
\hline oct $/ 04$ & 17.50 & 14.36 & 21.34 \\
\hline nov/04 & 16.28 & 12.28 & 21.57 \\
\hline may/05 & 22.93 & 19.65 & 26.74 \\
\hline aug/05 & 15.75 & 13.3 & 18.65 \\
\hline jun/06 & 26.94 & 23.22 & 31.26 \\
\hline jul/06 & 25.00 & 21.86 & 28.58 \\
\hline aug/06 & 15.12 & 13.8 & 15.57 \\
\hline apr/07 & 23.21 & 18.65 & 28.89 \\
\hline jul/07 & 15.16 & 13.21 & 17.4 \\
\hline aug/07 & 24.80 & 20.88 & 29.46 \\
\hline jun/09 & 31.90 & 23.44 & 43.42 \\
\hline Mean Value & 21.70 & 17.81 & 26.45 \\
\hline Standard Deviation & 5.72 & 4.33 & 8.02 \\
\hline $\begin{array}{l}\text { Coefficient of } \\
\text { Variation }\end{array}$ & 26.84 & 24.77 & 30.90 \\
\hline
\end{tabular}




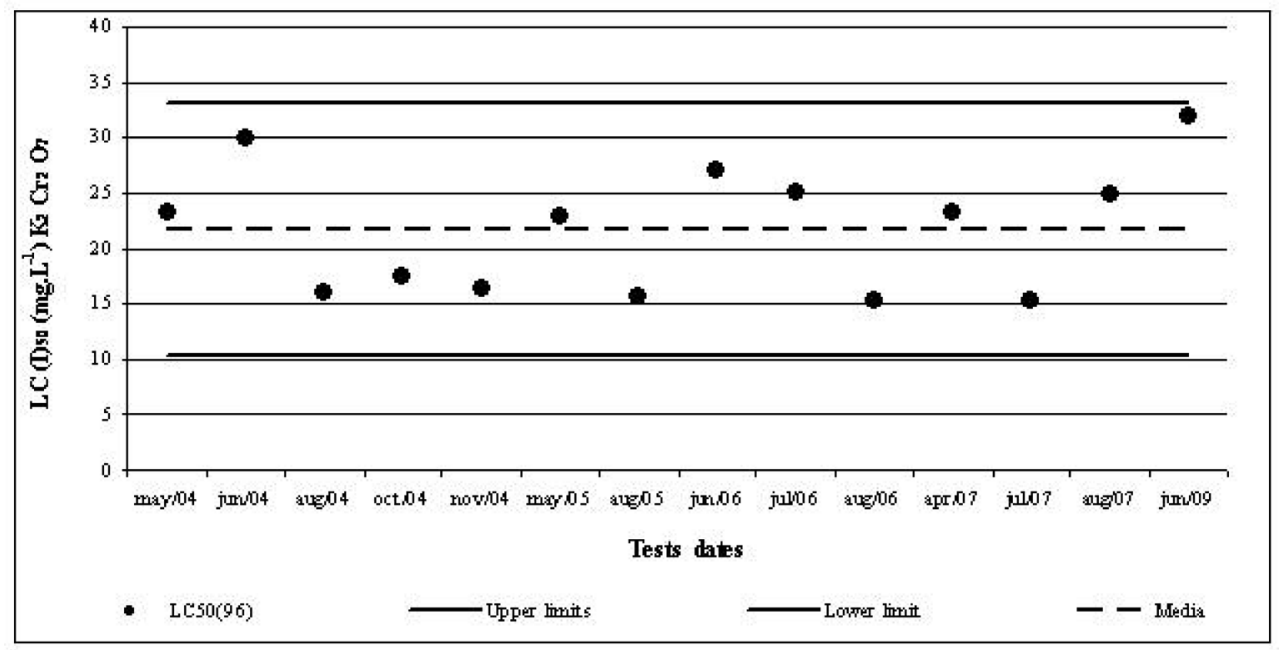

Figura 1 - Sensitivity control chart to Nitokra sp for potassium dichromate.

Table 4 - Sensitivity of some test-organisms to potassium dichromate.

\begin{tabular}{|c|c|c|c|c|}
\hline Test-Organism & & $\mathbf{K}_{2} \mathbf{C r}_{2} \mathbf{O}_{7}\left(\mathrm{mg} \cdot \mathrm{L}^{-1}\right)$ & $\begin{array}{l}\text { Exposure Time } \\
\text { and Effect }\end{array}$ & References \\
\hline \multirow{3}{*}{ Echinoids } & Lytechinus variegatus & 1.41 & 24h - Chronic & $\begin{array}{c}\text { Resgalla \& Laitano, } \\
2002\end{array}$ \\
\hline & Arbacia Lixula & 2.08 & 24h - Chronic & Maximo et al., 2008 \\
\hline & Mellita quinquiesperforata & 1.46 & 24h - Chronic & Laitano et al., 2008 \\
\hline \multirow{3}{*}{ Fishes } & P. mesopotamicus $(\mathrm{Pacu})$ & 144.5 & $96 \mathrm{~h}-$ Acute & \multirow{3}{*}{ Cruz et al., 2008} \\
\hline & H. eques (Matogrosso) & 130.79 & $96 \mathrm{~h}-$ Acute & \\
\hline & P. caudimaculatus (Guarú) & 154.39 & $96 \mathrm{~h}-$ Acute & \\
\hline \multirow{6}{*}{ Crustaceans } & Tiburonella viscana & 11.21 & $48 \mathrm{~h}-$ Acute & Abessa \& Sousa, 2003 \\
\hline & \multirow{3}{*}{ Tisbe biminiensis } & 22.2 & $48 \mathrm{~h}-$ Acute & \multirow{3}{*}{$\begin{array}{c}\text { Araújo-Castro et al., } \\
2009\end{array}$} \\
\hline & & 13.84 & $72 \mathrm{~h}-$ Acute & \\
\hline & & 9.45 & $96 \mathrm{~h}-$ Acute & \\
\hline & \multirow{2}{*}{ Nitokra sp } & 55.61 & $48 \mathrm{~h}-$ Acute & \multirow{2}{*}{ Present study } \\
\hline & & 21.70 & 96h - Acute & \\
\hline
\end{tabular}

as well as in ecotoxicological evaluations of environmental samples with variable salinity.

\section{CONCLUSIONS}

Nitokra sp is a native species of the Cananéia Estuary - São Paulo State, Brazil, and it is easily maintained in culture. Its short life cycle allows obtaining a great number of organisms in a short period of time, optimizing it use in routine toxicity testing.

Toxicity evaluation of ammonia toxicity and a reference compound was successful. Nitokra sp has proved to be a value species for use in environmental sample evaluation, especially in those obtained from estuarine regions.

Acknowledgments: The authors would like to thank Guilherme Lotufo and Denis Moledo de Souza Abessa for searching for and isolating Nitokra sp, the Laboratory of Marine Microorganisms of the Oceanographic Institute for the micro-algae supply used to feed and maintain Nitokra sp culture, and to $\mathrm{CNPq}$ for the partial financial support.

\section{REFERENCES}

ABESSA, D. M. S., 2002, Avaliação da qualidade de sedimentos do Sistema Estuarino de Santos, SP, Brasil. PhD. São Paulo: Universidade de São Paulo. 340 p.

ABESSA, D. M. S. \& SOUSA, E. C. P. M., 2003, Sensitivity of the amphipod Tiburonella viscana to $\mathrm{K}_{2} \mathrm{Cr}_{2} \mathrm{O}_{7}$. Braz. Arch. Biol. Technol., 46(1): 53-56. doi: 10.1590/S151689132003000100009.

ARAÚJO-CASTRO, C.M.V., SOUZA-SANTOS,L.P., TORREIRO, A. \& GARCIA, A. G., 2009, Sensitivity of the marine benthic copepod Tisbe biminiensis (copepoda hapacticoida) to potassium dichromate and sediment particle size. Braz. J. Oceanogr., 57(1): 33-41. doi: 10.1590/S1679-87592009000100004.

ARAÚJO, C. V. M., DIZ, F. R., TORNERO, V., LUBIÁN, L. M., BLASCO, J. \& MORENO-GARRIDO, I., 2010, Ranking sediment samples from three Spanish estuaries in relation to its toxicity for two benthic species: The microalga Cylindrotheca closterium and the copepod Tisbe battagliai. Environ. Toxicol. Chem., 29(2): 393-400. doi: 10.1002/etc.46.

BEJARANO, A. C., MARUYA, K. A. \& CHANDLER, G. T., 2004, Toxicity assessment of sediments associated with various 
land-uses in coastal South Carolina, USA, using a meiobenthic copepod bioassay. Mar. Pollut. Bull., 49: 23-32. doi: 10.1016/j. marpolbul.2004.01.004.

BOARDMAN, G. D., STARBUCK, S. M., HUDGINS, D. B., LI, X. \& KUHN, D. D., 2004, Toxicity of ammonia to three marine fish and three marine invertebrates. Environ. Toxicol., 19(2): 134142. doi: $10.1002 /$ tox. 20006.

BOWER, C. E. \& BIDWELL, J. P., 1978, Ionization of ammonia in seawater. Effects of temperature, $\mathrm{pH}$ and salinity. J. Fish. Res. Board Can., 35: 1012-1016. doi: 10.1139/f78-165.

BREITHOLTZ, M., NYHOLM, J. R., KARLSON, J. \& ANDERSSON, L., 2008, Are individual NOEC levels safe for mixtures? A study on mixtures toxicity of brominated flame retardants in the copepod Nitocra spinipes. Chemosphere, 10421049. doi: 10.1016/j.chemosphere.2008.05.004.

BURATINI, S. V. \& BERTOLETTI, E., 2006, Análise estatística, p.221-249. In: P. A. Zagatto \& E. Bertoletti, (eds.). Ecotoxicologia Aquática - Princípios e Aplicações. $1^{\mathrm{a}}$ ed. São Carlos: Editora Rima. 478 p.

COULL, B. C., 1990, Are members of the meiofauna food for higher trophic levels? Trans. Am. Microscopical Soc., 109(3): 233-246.

COULL, B. C. \& CHANDLER, G. T., 1992, Pollution and meiofauna. Field, laboratory and mesocosms studies. Oceanogr. Mar. Biol.: An Annual Review, 30: 191-271.

CRUZ, C., CUBO, P., GOMES, G. R., VENTURINI, F. P., GUILHERME, P. E. \& PITELLI, R. A., 2008, Sensibilidade de peixes neotropicais ao dicromato de potássio. J. Braz. Soc. Ecotoxicol., 3: 53-55. doi: 10.5132/jbse.2008.01.008.

DOMINGUES, D. F. \& BERTOLETTI, E., 2006, Seleção, manutenção e cultivo de organismos aquáticos. In: P. A. Zagatto \& E. Bertoletti (eds.). Ecotoxicologia Aquática - princípios e aplicações. $1^{\mathrm{a}}$ ed. São Carlos: Editora Rima. p.153-184.

ENVIRONMENT CANADA, 1990, Guidance document on control of toxicity test precision using reference toxicants. Report EPS 1/RM/12. 85 p.

FRIAS-ESPERICUETA, M. G., HARFUSH-MELENDEZ, M. \& PÁEZ-OSUNA, F., 2000, Effects of ammonia on mortality and feeding of postlarvae shrimp Litopenaeus vannamei. Bull. Environ. Contam. Toxicol., 65: 98-103. doi:10.1007/ s001280000100.

GIERE, O., 2009, Meiobenthology. The Microscopic Motile Fauna of Aquatic Sediments. Berlin: Springer-Verlag. 527 p.

HACK, L. A., TREMBLAY, L. A., WRATTEN, S. D., FORRESTER, G. \& KEESING, V., 2008, Toxicity of estuarine sediments using a full life-cycle bioassay with the marine copepod Robertsonia propinqua Ecotoxicol. Environ. Safety, 70(3): 469-474. doi: 10.1016/j.ecoenv.2007.12.008.

HAGOPIAN-SCHLEKAT, T., CHANDLER, G. T. \& SHAW, T. J., 2001, Acute toxicity of five sediment -associated metals, individually and in a mixture, to the estuarine meiobenthic harpacticoid copepod Amphiascus tenuiremis. Mar. Environ. Res., 51: 247-264.

HAMILTON, M. A., RUSSO, R. C. \& THURSTON, R. V., 1977, Trimmed Spearman-Karber method for estimating median lethal concentrations in toxicity bioassays. Environ. Sci. Technol., 12: 714-719.

KLOSTERHAUS, S. L., DIPINTO, L. M. \& CHANDLER, T., 2003, A comparative assessment of azinphosmethyl bioaccumulation and toxicity in two estuarine meiobenthic harpacticoid copepod. Environ. Toxicol. Chem., 22(12): 2960-2968. doi: 10.1897/02-411.

KWOK, K. W. H., LEUNG, K. M. L., BAO, V. W. W. \& LEE, J., 2008, Copper toxicity in the marine copepod Tigropus japonicus: Low variability and high reproducibility of repeated acute and life-cycle tests. Mar. Pollut. Bull., 57: 632-636. doi: 10.1016/j. marpolbul.2008.03.026.

LAITANO, K. S., GONÇALVES, C. \& RESGALLA JR., C., 2008, Viabilidade do uso da bolacha do mar Mellita quinquiesperforata como organismo teste. J. Braz. Soc. Ecotoxicol., 1: 9-14. doi: 10.5132/jbse.2008.01.002.

LAMBERSON, J. O., DE WITT, T. H. \& SWARTZ, R. C., 1992, Assessment of sediment toxicity to marine benthos. In: G. A. Burton Jr., (ed.). Sediment Toxicity Assessment. Chelsea: Lewis Publisher. p. 183-211.

LAPOTA, D., DUCKWORTH, D. \& WORD, J. Q., 2000, Confounding factors in sediment toxicology. San Diego: SPAWAR Systems Center, pp. 1-19.

LOTUFO, G. R. \& FLEEGER, J. W., 1997, Effects on sedimentassociated phenanthrene on survival, devlopment and reproduction of two species of meiobenthic copepods. Mar. Ecol. Prog. Ser., 151: 91-102. doi: 10.3354/meps 151091.

LOTUFO, G. R. \& ABESSA, D. M. S., 2002, Testes de toxicidade com sedimento total e água intersticial estuarinos utilizando copépodos bentônicos. In: I. A. Nascimento, E. C. P. M. Sousa \& M. G. Nipper, (eds.). Métodos em ecotoxicologia marinha: aplicações no Brasil. São Paulo: Artes Gráficas. p.151-162.

MACKIN, J. E. \& ALLER, R. C., 1984, Ammonium adsorption in marine sediments. Limnol. Oceanogr., 29: 250-257.

MARASCHIN, M. L. S., SCHORK, G., POLEZA, F. \& RESGALLA JR., C., 2008, Revisão do protocolo de teste de toxicidade aguda com o tanaidáceo Kalliapseudes schubartii. In: X Congresso Brasileiro de Ecotoxicologia, ed. Livro de Resumos. Bento Gonsalves - RS.

MAXIMO, M. V., MOTTOLA, L. S. M. \& RESGALLA JR., C., 2008, Sensibilidade do ouriço Arbacia lixula (Echinodermata: Echinoidea) em testes de toxicidade. J. Braz. Soc. Ecotoxicol., 3: 47-52. doi: 10.5132/jbse.2008.01.007.

PANE, L., GIACCO, E., CORRÁ, C., GRECO, G., MARIOTTINI, G. L., VARISCO, F. \& FAIMALI, M., 2008, Ecotoxicological evaluation of harbor sediments using marine organisms from different trophic levels. J Soil Sediments, 8(2): 74-79. doi: 10.1065/jss2008.02.272.

RAND, G. M., WELLS, P. G. \& MCCARTY, L. S., 2000, Introduction to aquatic toxicology. In: G. M. Rand, (ed.). Fundamentals of Aquatic Toxicology. Effects, Envionmental Fate and Risk Assessment. $2^{\text {nd }}$ edition. New York: Taylor \& Francis. 1125 p.

REBELO, M. F., 1996, Caracterização de efeitos letais e subletais da exposição aguda a amônia em Chasmagnathus granulata (Decapoda-Grapsidae) Dana, 1851. Dissertação de Mestrado. Porto Alegre: Fundação Universidade do Rio Grande do Sul.

RESGALLA JR., C. \& LAITANO, K. S., 2002, Sensibilidade dos organismos marinhos utilizados em testes de toxicidade no Brasil. Notas Técnicas Facimar, 6: 153-163.

RUPPERT, E. E., FOX, R. S. \& BARNES, R. D., 1996, Zoologia dos Invertebrados. São Paulo: Roca. 1029 p.

THURSTON, R. V., RUSSO, R. C.\& EMERSON, K., 1979, Aqueous Ammonia Equilibrium - Tabulation of Percent Un-Ionized Ammonia. EPA-600/3-79-091. Minnesota: U.S. Environmental Protection Agency, $428 \mathrm{p}$.

USEPA, United States Environmental Protection Agency, 1992, Short Term Method for estimating the chronic toxicity of effluents receiving waters to freshwater organisms. EPA/600/4/91/022. 335 p.

USEPA, 2001, Method for assessing the chronic toxicity of marine and estuarine sediment - associated contaminants with the amphipod Leptocheirus plumulosus. EPA/R-01/020.

WHITFIELD, M., 1974, The hydrolisis of ammonia íons in sea water 
- A Theoretical Study. J. Mar.Biol. Assoc. U.K., 54: 565-580. doi: $10.1017 / \mathrm{S} 002531540002275 \mathrm{X}$.

WHITFIELD, M., 1978, The hydrolysis of ammonium ions in sea water-experimental confirmation of predicted constants at one atmosphere pressure. J. Mar.Biol. Assoc. U.K., 58: 781-786. doi: $10.1017 / \mathrm{S} 0025315400041436$.

ZAGATTO, P. A. \& BERTOLETTI, E., 2006, Ecotoxicologia Aquática - princípios e aplicações. São Carlos: Editora Rima. 478 p. 